\title{
Imprints of the Thing in Itself: Li Zehou's Critique of Critical Philosophy and the Historicization of the Transcendental
}

\author{
Ady VAN DEN STOCK*
}

\begin{abstract}
Kant's concept of the "thing in itself" constitutes a formidable challenge to the project of "(anthropological-)historical ontology" with which the name of Li Zehou has become synonymous. Li's radical reinterpretation of Kant's critical philosophy, which locates the conditions of the possibility of knowledge and experience within historical and social evolution and thus seeks to allow for a form of human self-determination, brings us face to face with the close relation between the epistemological/ontological and normative dimensions of the notion of the thing in itself. My paper attempts to tease out some of the conceptual presuppositions and repercussions of Li's approach to the thing in itself in the Critique of Critical Philosophy (Pipan zhexue zhi pipan 批判哲学之批判), while locating his reading in the broader context of Kant's transcendentalism.
\end{abstract}

Keywords: Li Zehou, modern Chinese philosophy, historical ontology, Immanuel Kant, thing in itself

\section{Dojemanje stvari po sebi: Li Zehoujeva Kritika kritične filozofije in historizacija transcendentalnega}

\section{Izvleček}

Kantov koncept »stvari po sebi« predstavlja izjemen izziv za projekt »(antropološko-) zgodovinske ontologije«, ki jo v veliki meri enačimo z imenom Li Zehouja. Lijeva radikalna reinterpretacija Kantove kritične filozofije, ki lokalizira pogoje možnosti spoznanja in izkustva znotraj zgodovinske in družbene evolucije in na ta način omogoča posebno obliko človeškega samodoločanja, nas sooča s tesno povezavo med epistemološko/ontološkimi in normativnimi razsežnostmi pojma stvari po sebi. Cilj pričujočega članka je kritično prevpraševanje nekaterih konceptualnih učinkov in predpostavk Lijevega razumevanja stvari po sebi, kakršno je izpostavljeno v njegovi knjigi Kritika kritične filozofije (Pipan zhexue zhi pipan 批判哲学之批 判), ter umestitev njegovih idej v širši kontekst Kantovega transcendentalizma.

Ključne besede: Li Zehou, moderna kitajska filozofija, zgodovinska ontologija, Immanuel Kant, stvar po sebi

Ady VAN DEN STOCK, Ghent University,

Department of Languages and Cultures, Belgium.

Email address: ady.vandenstock@ugent.be

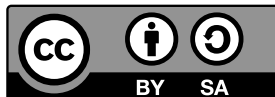




\section{Prologue: Li Zehou's Historical Ontology}

The philosophy of Li Zehou 李泽厚 (b. 1930), one of the most influential and creative living Chinese thinkers, is arguably unique in modern Chinese thought for the willingness (and indeed eagerness) it has shown to open up philosophical thought to the contingency of historical change as well as to other domains of cognitive, practical, and social activity, most notably the aesthetic dimension of human existence. ${ }^{1}$ In a sense, Li's paradigmatic proposal to formulate a "historical ontology" (lishi bentilun 历史本体论), or “anthropological-historical ontology” (renleixue lishi bentilun 人类学历史本体论), already presupposes that the "what is ...?" questions with which philosophical thought typically (though of course not exclusively) concerns itself have to be transformed into questions of the following type: "how did ... come into being?" or "what were the conditions for ... to become?" 2 Such a properly transcendental approach to ontological inquiry, which asserts the necessity of investigating the conditions within which knowledge of what "is" becomes possible before allowing anything resembling ontological judgements to take place, ${ }^{3}$ is thus, ideally at least, historical through and through. The conditions of the possibility of knowledge are, according to Li's radical reinterpretation of Kant's critical philosophy, themselves also a product of human activity throughout history, and thus equally conditioned and contingent, instead of remaining safely isolated from natural and social evolution. This

1 Indeed, for $\mathrm{Li}$, “aesthetics is first philosophy” (美学是第一哲学) ( $\mathrm{Li}$ 2016, 568).

2 Already in one of his earliest published texts, an article entitled "On Aesthetic Feeing, Beauty, and Art” (Lun meigan, mei, yu yishu 论美感、美与艺术) from 1956, which contains his notion of “sedimentation" (see below, still called “accumulation" (jilei 积累) here; see Li 1956, 48, 71) in embryonic form, $\mathrm{Li}$ emphasized the mediated nature of all forms of knowledge and experience in the context of his critique of Zhu Guangqian's 朱光潜 (1897-1986) “idealist” aesthetics. While $\mathrm{Li}$ concedes that aesthetic feeling (meigan 美感) does indeed first of all "present itself to us in the form of an intuition” (在这样一种直觉的形式中呈砚出), he goes on to point out: “That which allows us to acquire knowledge concerning a particular object through intuition is the fact that we have unconsciously come to form an understanding of this particular object and of how it relates to the totality of life through the influence of everyday existence and the formative influence of culture." (我們所以 能够从直觉中对个别事物有知識, 是因为我们在日常生活和文化教养的影响和熏陶下, 不自 觉地形成了对这个个别事物的了解，对这个事物在整个生活中的关系和联系的了解。) ( $\mathrm{Li}$ 1956, 45-46, emphasis in the original) Accordingly, even something as seemingly unmediated and spontaneous as the experience of beauty is thoroughly historical in nature, since beauty is not simply a property of nature, but rather is essentially social in character. Or as Li himself put it: "Natural beauty is quite simply a particular form of existence of beauty within social life (actual beauty), that is to say, an 'alienated' form of existence." (自然美就只是社会生活的美(现实美)的一种特殊的存在形 式, 是一种“异化” 的存在形式。) (Li 1956, 60, emphasis in original) For more background and a detailed analysis of this youthful text, see Rošker 2019, 9-10, 186-96, 300-1 (notes 4 and 6).

3 In Kant's original definition in the Critique of Pure Reason: "I call all knowledge transcendental which deals not so much with objects as with our manner of knowing objects insofar as this manner is to be possible a priori." (Kant 2007, 52 (B25), my italics) 
is also one of the main motivations behind Li's plea for replacing what he takes to be the dominant conception of “subjectivity" (zhuguanxing 主观性) as purely epistemological in orientation with that of "subjectality" (zhutixing 主体性) (see $\mathrm{Li}$ 1999). From the perspective of "subjectality", "the human subject [appears] as sensual and embodied ( $t i$ 体), and already embedded, prior to all perception, in a historical and social context that shapes the categories with which it organizes its perceptions of reality" (Chong 1999, 140). Hence, what Li calls "subjectality" compromises the totality of human existence in its objective "techno-social" (工 艺社会) and subjective “cultural-psychological” (see below) as well as individual aspects (see $\mathrm{Li} 2000,27 ; \mathrm{Li} 2018 /[1979], 70 / 94) .{ }^{4}$ The "subject" of "subjectality" is not merely able to "think" or to "know", but can also act, work, invent, produce, congregate, cooperate, desire, feel, remember, and so on. Moreover, these activities do not occur within a contextless blank space, but are in themselves already marked and shaped by historical, social, and cultural developments. As such, it is hard to miss the significance of the fact that $\mathrm{Li}$ insists on calling himself a "historicist” (Li 2018, 229).

At the same time, for $\mathrm{Li}$, this basic methodological outlook, which can be briefly described as involving a thorough historicization of the transcendental, is exemplified by what he takes to be a uniquely Chinese conception of "being" as fundamentally a matter of "becoming" (see for example Li 2010, 52; Li 2016, 437). Additionally, Li approaches the Confucian perspective on (human) existence as occupying a privileged position within the Chinese tradition. ${ }^{5} \mathrm{He}$ believes that the "one-world view" (一个世界观) of this “Confucian-dominated" (Li 2010, 219) cultural tradition effectively precluded the bifurcation between unconditioned and conditioned or a priori and a posteriori, which Li sees as intrinsically linked with the very concept of the transcendental:

[f] or the Chinese, "transcendental" or a priori cannot be the last word. The Chinese mind would ask, why is something "transcendental", or where does the a priori come from? Because of this "one-world view", it would also be difficult to accept the idea of something "absolutely independent of all experience." $6[\ldots]$ On the contrary, filled with a sense of history, the Chinese mind always searches for some historical interpretation. Thus,

4 References to the Critique of Critical Philosophy will include the Chinese edition ( $\mathrm{Li}$ [1979]) as well as the recent English translation by Jeanne Haizhen Allen and Christopher Ahn from 2018.

5 See for example Li 1994, 45; Li 2018, 221. Crucially, as Jana Rošker points out, "Li pushes the origins of Chinese culture further back than the majority of Chinese scholars by suggesting that Confucianism originated from the rationalized shamanism with the Duke of Zhou as its initiator" (Rošker 2019, 109). 
the "transcendental" and the a priori must also have their roots in this world, in the movement of history. (Li 1999, 180)

Similarly, Li's dismissive attitude toward any form of "ontology" (bentilun 本体 论) which involves a division of reality into categorically distinct spheres bears witness to this dual strategy of historicization and culturalization as well. More precisely, his displacement of the category of the noumenal (benti 本体) into the immanence of "one world", as something performatively embodied ( $t i$ 体) within the concreteness of human existence and material practice in society, is often presented as a distinctly Chinese insight and accomplishment, albeit one with a more universal validity:

We have no philosophical questions of being or different realms of phenomenon and noumenon, for our is not a dualistic world view. We translate noumenon as benti [本体], a word coined from ben (root, origin) and $t i$ (stem, body) [...] So instead of a study of being, bentilun [本体论] is a study of the ben (root, origin) and $t i$ (stem, body) of things. Clearly, this approach views the origin of things from a more biological and historical perspective than from that of metaphysics. I suggest that the root and body of human practice is benti and, further, that human emotions (subjects) and tools (objects) are benti. I like to call [this] bentilun, the study of benti, or historical ontology [...] In addition, within the Chinese oneworld view, the existence of everything is connected with the existence of human beings; hence, being cannot be separated from the existence of human beings. The Chinese people emphasize that the thinking subject cannot be separated from the acting subject, that consciousness cannot be separated from human material (bodily) existence. ( $\mathrm{Li} 2006,40)^{7}$

7 As he writes in the postscript to The Chinese Aesthetic Tradition (Huaxia meixue 华夏美学): “What is the noumenon [benti 本体]? It is ultimate reality, the origin of everything. According to the Confucian-based Chinese tradition, the noumenon is not nature, for a universe without humanity is meaningless. Nor is the noumenon a deity, for to ask humans to prostrate themselves before a god would not fit with the notions of 'partnering in the transformation and nurturing of all things' or 'establishing the heart of heaven and earth.' It must follow, then, that the noumenon is humankind itself." (Li 2010, 223) The following passage from the work of another prominent Chinese thinker, Zhao Tingyang 赵汀阳 (b. 1961), has a very similar ring to it, even if it goes much further in confusing the distinction between epistemological and normative issues: "The problem of a being as a thing 'in itself' is strange for Chinese philosophy, since nothing can be a thing as such unless it is defined in terms of its relations with other things. This means that relations, rather than things, need to be meaningfully examined. From the viewpoint of relationships, it is unreasonable to say 'a thing is as it is', for a thing is never as it is by itself; it is made as such and such in certain relations in which it is involved. Rather than being a real presence, a 'thing' is merely a linguistic invention to facilitate representation. Relations are thus the ontological condition for a thing to be present as such; so much so that existence presupposes co-existence, and co-existence determines existence." (Zhao 2009, 15) 
Hence, within Li Zehou's own line of reasoning, the category of (Chinese) "culture" would seem to count as something located in an indeterminate grey zone between the historical and transcendental: while having been shaped within the context of the contingent "movement" of historical evolution, the process which Li describes as the "sedimentation" (jidian 积淀) ${ }^{8}$ of experiences, emotions, and knowledge has led to the appearance of a distinctive and relatively stable Chinese "cultural-psychological formation" (wenhua-xinli jiegou 文化一心理结构) which displays a strong degree of independence from history and change. ${ }^{9}$ Ironically then, Li claims that it was precisely the fundamental "pragmatic rationality" (shiyong lixing 实用理性) of this “cultural-psychological formation" which made the Chinese as a people positively predisposed toward historical materialism and Marxism (see Li 1985, 315-16). To be sure, this aspect of Li's "historical ontology" raises a considerable number of theoretical questions which cannot be directly or exhaustively addressed here. ${ }^{10}$ Doing so would require us to offer an adequate reconstruction and presentation of Li's combined interest in Marx's historical materialism and Confucianism, an unlikely conceptual partnership which is further complicated by a decade-long engagement with Kant reaching back to his landmark study A Critique of Critical Philosophy (Pipan zhexue zhi pipan 批判哲学之 批判) from 1979. Instead of laying out such a big picture in the following pages, I will limit myself to presenting a small case study of what is perhaps the single most unlikely and unwieldy object of the sort of radical materialist historicization proposed by Li Zehou, namely the Kantian concept of the "thing in itself" (das Ding an sich, usually translated into Chinese as wu zishen 物自身 or wu ziti 物自

8 In one of Li's terse definitions: "By sedimentation (jidian), I mean that human nature, which is a cultural psychological construction of uniquely human capabilities, was formed from the historical processes of using tools, social interaction, and the rituals of shamanism. What is human has been sedimented into individuals, the rational into the sensuous, and the social into the natural." ( $\mathrm{Li}$ 2006, 88)

9 Describing the role played by Confucianism in the genesis of the Chinese "cultural-psychological formation", Li writes: "Kinship, psychology, humanism, and personal character finally formed the organic totality of this mode of thinking characterized by pragmatic reason. This thinking is able to form an organic totality because within the mutual containment and interactive functioning of these factors it achieves equilibrium, self-regulation, and self-development. It moreover possesses a certain closedness, regularly repelling external disruption or harm." $(\mathrm{Li} 2018,135)$ This passage is a quote from an earlier and crucial text from 1980, "A Reevaluation of Confucius" (Kongzi zai pingjia 孔子再评价), later republished as the first chapter of On the History of Ancient Chinese Thought (Zhongguo gudai sixiang shi lun 中国古代思想史论) from 1985.

10 For a few additional comments, see Van den Stock (forthcoming). In Liu Kang's view, "the historical materialist distinction of base/superstructure seems to be dissolved or undermined by Li Zehou's own predominantly culturalist resolutions” (Liu 1992, 129). Similarly, Jing Wang pertinently remarks: "Li Zehou's vacillating rhetoric about cultural sedimentation-that it is a completed circle at one moment and a kinetic motion at the next-indicates that he cannot decide whether superstructure is a mere epiphenomenon of economy or a semiautonomous force that interacts with and sometimes even overpowers economic constraints." (Wang 1996, 99-100) 
体). ${ }^{11}$ In the process, I will attempt to place Li's reinterpretation of this contested and highly complex notion, and of Kant's critical philosophy in general, within the broader context of modern intellectual history and tease out some of the conceptual presuppositions and repercussions of Li's reading of the thing in itself.

\section{Interlude: Sense and Reference of the Thing in Itself}

Before going on, we should perhaps pause here to ask what it might mean to say, as Li Zehou does, that "the 'transcendental' and the a priori must also have their roots in this world, in the movement of history." After all, how can something like the "thing in itself", a notion that explicitly designates the limits of human knowledge as such, and thus refers to an absolute boundary immune to the contingency of historical (as well as cultural) variability, be not only affected by, but even, in some sense, grounded in historical change? It may be objected that this naive question involves a confusion between the thing in itself as a concept on the one hand, and what the latter actually designates on the other, that it to say, between "sense" and "reference", respectively. There can be, within this line of reasoning, historically and culturally variable interpretations of the "thing in itself", but the latter, the thing in itself in itself, so to speak, remains completely impervious to any form of contingency and variability. However, Li Zehou's claim to upset (if not altogether annul) the boundaries between the transcendental and the historical by means of the concept of "sedimentation" presents itself as much more ambitious and does not stop at the rather straightforward observation that the limits of knowledge can be (and have been) conceived of in different ways throughout history and across different cultures. ${ }^{12}$ Rather, he seems to mean quite literally that

11 For a detailed study of the reception and translation of this concept in modern China, see Kurtz 2011. As Kurtz succinctly notes: "Although never intended as a theoretically productive notion and repeatedly denigrated by Kant himself as a 'fiction' (Unding) and a mere 'object of thought' (Verstandeswesen) with no 'positive meaning' or 'use' (KrV B274; B305-15), Chinese philosophers have insisted on treating 'things in themselves' as a necessary and intelligible concept, and devoted numerous studies to the ways in which noumena may be known despite Kant's repeated, and perhaps even 'dogmatic' claims to the contrary." For more general overviews of the Chinese reception of Kant, see Müller 2006; Lee 2016; Xu 2016.

12 An interesting example pertinent to the context of the present article can be found in "On the Heavens” (Zhutian jiang 諸天講), a text by Kang Youwei 康有爲 (1858-1927) (draft completed in 1886, revised in 1926 and only published in 1930; see Lee 2016,2), which touches upon the Kant's nebular hypothesis concerning the formation of the solar system as well as his epistemological skepticism concerning the existence of God. See Kang 1930, 92-94. As Bo Xu points out, in his discussion, Kang "quietly transferred this Kantian stress on the limits of human cognition to the limits of Western science [...] Kang therefore did not embrace Kant's agnostic stance wholeheartedly, but adopted it merely in the sense that it demarcated a boundary for Western science, within which only material-corporeal things were to be studied” (Xu 2016, 27). Hence, 
everything usually thought of as "transcendental" (in formal terms, that which is not reducible to what it serves as a condition of the possibility for, hence not to be confused with "transcendent"13), including, as we will see further on, the infamous Ding an sich, is historically constituted, without however being completely dissolvable into the immanently given flux of contingent events. In the latter case, we would be left with a phenomenalist rather than a transcendental account, even when we are dealing with a radically different sort of transcendentalism than the Kantian one sort (i.e. one not grounded in "subjectivity", but "subjectality"). Moreover, if we recall that what Kant means by the thing in itself does not refer to something which remains (perhaps forever) unknown because of certain empirical or technical impediments (say the limited frequency range of the human ear or the absence of a powerful enough Hadron Collider), but involves abstracting from all features of human sensibility and all categories of the understanding (see for instance Kant 2007, 258, B306-7), thus including notions such as "invariable" or "unchangeable", it becomes clear that this distinction between the sense and reference of the thing in itself is perhaps not so easy to draw, at least not in these terms. Indeed, how are we supposed to get a sense and make sense of something which defies all the coordinates we have at our disposal for conceptually determining and representing it, even those which operate ex negativo (invariable, unchangeable)? With what sort of "thing" are we dealing when its only identifiable property seems to be that of being radically unknowable and foreclosed to any possibility of being positively designated? And if things in themselves are merely conceptual abstractions or placeholders, in what sort of relation can they possibly stand to the (in principle) knowable objects of experience which they accompany (and, for Kant, must necessarily be posited as accompanying ${ }^{14}$ ) as shadowy twins?

decades before the famous debates concerning the respective limits of scientific and humanist forms of reasoning in Republican China, Chinese thinkers had already started examining the modern epistemic space from the perspective of cultural difference as an observational scheme.

13 On this point, see Li 2018/[1979], 52/70-71; cf. Li 1978, 45. In the mainland Chinese literature, the term "transcendental" is usually rendered as xianyan 先验 (literally, "before experience"), whereas a priori is translated as xiantian 先天 ("before heaven," a complex term already widely used in Neo-Confucian as well as Daoist thought reaching back to the Yijing 易經) and “transcendent" as chaoyan 超验 (“surpassing experience”) or chaoyue 超越 (to add to the confusion, this term is often used as the equivalent of "transcendental" in the writings of scholars from Hong Kong and Taiwan). These terms were already used by Lan Gongwu 蓝公武 (1887-1957), author of the first Chinese translation of the Critique of Pure Reason (made on the basis of Norman Kemp Smith's (1872-1958) English translation). As is the case for most of the technical and specialized vocabulary in modern Chinese, the translation efforts of Japanese scholars during the Meiji period played a decisive role in this case as well, particularly the work of Kuwaki Gen'yoku 桑木厳翼 (1874-1946). For a brief historical study of Chinese translations of these terms, see Wen and Chen 2011.

14 As Nicholas Rescher explains: "A thing in itself whose nature is brought within the reach of the categories of understanding is ipso-facto unable to do the job of endowing the appearances with 
To be sure, the problem and ambiguity we encounter here is already very much present in Kant's own work, as the entire history of post-Kantian German idealism bears out: on the one hand, the thing in itself merely designates "a limiting concept $[. .$.$] intended to keep the claims of sensibility within proper bounds" (Kant$ 2007, 261, B311-12). As such, it is not so much a transcendent beyond, but rather (at most) a purely hypothetical correlate of our objects of knowledge, stripped of all of the conditions which make such knowledge possible. In this capacity, it functions as the unknowable cause of our representations of things insofar as they are attuned and accessible to us, that is to say, as phenomena. On the other hand however, Kant concedes that while the thing in itself cannot be known, and that human knowledge is only possible precisely because we can only know things as phenomenal appearances, we are still able to think it (see Kant 2007, 23, Bxxvii). As such, the thing in itself is a "thought entity" (ens rationis), or, more colloquially, a "thing of thought" (Gedankending) (see Kant 2007, 283-84, B346-84). Hence, the very ability Kant ascribes to human beings to think, however approximately, the thing in itself suggests that the latter is located on either side of the boundaries of human cognitive activity. It designates a limit to knowledge that still has one foot, so to speak, in the domain of the knowable, at least insofar as the latter is identified with what is thinkable (which are not identical categories for Kant ${ }^{15}$ ). As Johann Gottlieb Fichte (1762-1814) argued in the Science of Knowledge (Wissenschaftslebre) (first version of 1794) with uncharacteristic clarity:

This fact, that the finite spirit must necessarily posit something outside itself (a thing in itself), and yet must recognize, from the other side, that the latter exists only for it (as a necessary noumenon), is that circle which it is able to extend into infinity, but can never escape (quoted in Rockmore 2010, 18).

Of course, Kant himself clearly distinguishes the circle described in such "thinking" from knowledge in the strict sense, which involves both sensible content and the forms supplied by the a priori categories of the understanding. In any case, this implies that the concept of the thing in itself is not some speculative eccentricity which can easily be eliminated from Kant's philosophy, nor from the process of human cognition as such. As Nicholas Rescher put it in a way similar to Fichte,

the intentionality of indicating something that stands altogether outside the phenomenal order to assure that appearances are appearances of something. A cognitively domesticated thing in itself would (ex hypothesi) not be able perform the key mission assigned to such things in the Kantian framework, viz. to provide a basis of externality for the objects of knowledge." (Rescher 1981, 295-96)

15 "The possibility of a thing can never be proved merely from the fact that its concept is not selfcontradictory, but only by being supported by a [sensible] intuition corresponding to it." (Kant 2007, 259, B309) 
it is of the very nature of human reason to construe the things of experience, the phenomena, as representations-that is, to take them to be correlative with underlying reality, to be not just appearances but appearances of things as they are in themselves (an sich selbst genommen) [...] (Rescher 1981, 297).

Crucially however, Rescher concludes that "[a]s is only fitting in the context of Kant's philosophy, their [things in themselves'] station within the final analysis is not ontological but epistemological (ibid., 298)."16

While I have no intention of disputing Rescher's analysis, we could add here that the implications of this last observation can vary considerably depending on the reach one ascribes to the terms "ontology" and "ontological". If we follow Heidegger ${ }^{17}$ as well as Li Zehou (along with many other modern Chinese philosophers) in treating the term "ontology" as fundamentally concerning a mode of questioning into the being of human beings in particular, it becomes clear that the purely "epistemological" status of things in themselves has implications reaching far beyond the confines of epistemology. ${ }^{18}$ Kant's own claim that the experience of ourselves as moral subjects constitutes some sort of pathway into the "in itself" allowing us to escape the confines of the phenomenal, which some commentators have viewed as a "carry-over of pre-critical language" (Schrader 1949, 38), already indicates as much. As such, for all the overall superficiality and blatant mistakes in Liang Qichao's 梁启超 (1873-1929) (in the Chinese context, pioneering) exposition of Kant's philosophy, his approach to the thing in itself as corresponding to a person's "true self" (zhenwo 真我) and as designating the freedom of a "higher form of life" (高等生命者) unaffected by contingency and empirical causality, was not that far off, at least insofar as Liang managed to identify the normative dimension of this notion (see Xu 2016, 29). ${ }^{19} \mathrm{In}$ more

16 According to Gerold Prauss's 1974 study Kant und das Problem der Dinge an sich, "in itself” (an sich) predominantly figures in Kant's writings not as an adjectival, but rather as an adverbial expression, that is to say, as a shorthand for "observed in itself" (an sich betrachtet) (See Vallicella 1983, 37). This would mean, paradoxically enough, that the "in itself" is simply another mode of observation, an approach which deprives the thing in itself from any ontological weight, since the verb "observing" (betrachten) which it modifies adverbially precisely undermines any claim to guarantee the ontological independence of an unobserved "in itself", as the sociologist Niklas Luhmann consistently maintained. See for example the succinct remarks in Luhmann 2013, 99-100.

17 "Understanding of Being is itself a definite characteristic of Dasein's being. Dasein is ontically distinctive in that it is ontological." (Heidegger 1927, 32)

18 Feng Qi’s 冯契 (1915-1995) “epistemology in a broad sense” (guangyi de renshilun 广义的认识论) is particularly worth mentioning here.

19 Liang's interpretation of the thing in itself, which he rendered using the Buddhist term wuru 物 如 (literally, the "suchness of things", or "things in their suchness"), can be found in a text from 1903/1904 entitled “The Theories of Kant, the Greatest Sage of the Modern Era” (Jinshi diyi dazhe 
general terms, the amount of enthusiasm, passion, and occasional vitriol Kant's thing in itself has managed to provoke for over two centuries since the appearance of the first Critique indicates that it is something which exerts a great degree of attraction as well repulsion on us, precisely because any conception of the "in itself" stands in a close relation to how the world exists "for us". In other words, whatever the referential value of the thing in itself may be, its sense clearly has implications for our understanding of human existence and, in this specific sense, has an ontological valence as well. Although this does not immediately bring us any closer to the thing in itself (indeed, how could it?), I will argue in more detail in the next section that this burdening of the thing-itself with considerable "ontological" and normative weight is of crucial importance for understanding Li Zehou's interpretation of this concept as well as its broader status in modern intellectual history.

\section{The Thing in Itself: The Transcendental in the Critique of Critical Philosophy (1979)}

The entire seventh chapter of Li Zehou's Critique of Critical Philosophy from 1979
(Li 2018/[1979], 189-213/239-72) is devoted to an extensive discussion and

Kangde zhi xueshuo 近世第一大哲康德之學説), the earliest systematic presentations of Kant's philosophy in Chinese, originally published in serialized form in the Xinmin congbao 新民叢 报. In this text, largely based on a selective reading of texts and translations by Nakae Chōmin 中江兆民 (1847-1901) (see Burtscher 2006; Huang 2014), Liang used concepts derived from Yogācāra Buddhism to introduce his Chinese readers to Kant, whom he presented as a veritable “sage” (shengren 聖人) (see Cheng 2001; Xu 2016, 28-30). According to Lee Ming-huei 李明 輝, Liang's somewhat rudimentary reading of Kant already foreshadows certain aspects of the much more sustained and elaborate interpretation offered by undoubtedly the most famous of all Chinese Kantians, Mou Zongsan 牟宗三 (1909-1995) (See Lee 2016, 7). As is well-known, Mou went much further than Liang in pushing the normative dimension of the thing in itself to the foreground. Rather than seeing it as a categorical limit to human knowledge, he attempted to positively redefine it as an "object" of intellectual intuition, a moral faculty which he claims to have been consistently confirmed and embraced in all major Chinese philosophical traditions, most notably Confucianism. This is why Mou argued that the distinction between the noumenal and the phenomenal is a matter of "value" and not of "fact" (see Mou 1975,1-20; for a detailed analysis which draws on the strong normative significance of the thing in itself in Kant's own writings, see Lee 2018; also see Van den Stock 2016, 299-347). It does not merely concern the conditions of the possibility of knowledge, but rather of existence as such, more precisely in a state of moral perfection. Since intellectual intuition does not operate under the normal conditions of knowledge, it stands to reason that such intuition should not be read in a narrowly cognitive sense. Borrowing a term from Heidegger, Mou stresses that the thing in itself is not, strictly speaking, an "object" (Gegenstand, duixiang 对象, i.e. something that stands opposed to something else) at all, but rather an "e-ject” (Ent-stand, zixiang 自相, “self-appearance") (Mou 1975, 104), something that shines forth from itself in the self-transparency of intuitive insight. 
analysis of the concept of the thing in itself (wu ziti 物自体). ${ }^{20}$ As is the case throughout the whole book, $\mathrm{Li}$ starts this chapter on what he calls the veritable “centre of Kant's whole system of philosophy” (整个康德哲学的中心) (Li 2018/ [1979], 189/239) with a more descriptive account, in order to gradually insert his own critical comments and develop an alternative interpretation which reflects the basic outlook of his own historical ontology. This outlook is summarized succinctly earlier on in his Critique in the context of a discussion of the Kantian categories of the understanding, which $\mathrm{Li}$ sees as originating in historically and socially determinate forms of practice:

what seems "transcendental" to an individual is actually abstracted from the long historical experience of the human community. Although they [the transcendental concepts of the understanding] cannot be directly induced from individual perception, they can be produced by historical social practice within empirical reality, and preserved in our science and culture. The transcendental can accumulate and develop so as to increasingly expand human beings' cognitive power.

但是对于个体似乎是 “先验” 的东西, 却是人类集体从漫长的历 史经验中抽取提升出来的。它们虽然不能从个体的感知中直接归 纳出来, 却能够从感性现实的社会实践的漫长历史活动中产生出 来，并保存在人们的科学、文化之中，不断积累发展着，使人的 知识能力日益扩大。(Li 2018/[1979], 128/164, translation amended)

At stake for Li in any discussion of the transcendental is accomplishing a shift from the ahistorical, and in this sense "abstract", viewpoint of individual subjectivity to a perspective which confers agency on human beings as a social collective. Viewed in this way, the transcendental (xianyan 先验) is that which allows the results of historical development, primarily those stemming from social labour as centred around the manufacture and creation of tools, which $\mathrm{Li}$ considers to be the "hard core of historical materialism" (Li 2018, vi), to be recovered within humanity as a totality evolving through time. The conditions of the possibility of knowledge are thus grounded in "empirical reality" (感性的现实) in a materialist fashion, but at the same time, the access human beings have to reality is assumed to be always already mediated by the accumulated results of previous cognitive and practical activity in social history. In other words, the conditions of the possibility of knowledge and experience which are the native territory of

20 The seventh chapter is the last one to fall under the division "epistemology" (renshilun 认识论) (covering six chapters in total) in Li's Critique, the other two main divisions being "ethics" (lunlixue 伦理学) (two chapters) and “aesthetics and teleology" (meixue yu mudilun 美学与目的论) (one chapter). 
the transcendental are only (heuristically) external (or "transcendent") to human beings insofar as they are analytically isolated from the "bigger self" (dawo 大 我), as the true agent of history in which their "smaller selves" (xiaowo 小我) (see Rošker 2019, 48) are grounded. Or, in a slightly earlier formulation: "The subject of knowledge is not the individual, and its starting point is not to be found in passive forms of observation such as sensation, perception, and imagination which belong to our animal nature. The subject of knowledge is a [human] collective [within a particular] age and social class, its starting point are concrete practical activities in society." (认识的主体不是个人, 出发点不是动物性的感觉、知 觉、表象等静观。认识的主体是时代社会阶级的集体, 出发点是具体的社 会实践活动。) (Li 1978, 47; cf. Li 2018/[1979], 201/255)

At this point, it is already worth indicating that for $\mathrm{Li}$, the true contemporary significance of Kant's Copernican turn, according to which, in Li's description, "[i]t is no longer a question of the subject reflecting the object, but rather of the subject constituting and constructing the object, demanding that the object meet the requirements of the subject” (不是主体反映客体, 而是主体构造、建立客 体; 要求客体来符合主体), lies in the fact that modern advances in science and technology, such as quantum physics and genetic engineering, bear witness to what he sees as a unprecedented manifestation of the "dynamic nature of human cognition" (人的认识能动性) (Li 2018/[1979], 34-35/52, translation amended). ${ }^{21}$ Such "dynamism" is both a sign of and a transcendental guarantee for the possibility of increasing the "cognitive power" of humanity as a whole. Hence, the identification of the transcendental with a materially grounded form of human practice is from the onset tied up with the normative requirement of autonomy and self-determination, one which necessitates a radical reinterpretation of the notion of the "self" as a transindividual form of "subjectality" (zhutixing 主体 性). Or, in what is perhaps Li's most condensed definition: "the question of the possibility of cognition can be answered only through an answer to the more basic question of how humanity (social practice) is possible” “认认识如何可能”只能建 筑在“人类”(社会实践) 如何可能的基础上来解答) (Li 2018/[1979], 201/255, translation amended; cf. Li 2018,v).

In the seventh chapter of his Critique, Li identifies three distinct but closely interrelated aspects of the concept of the thing in itself in Kant's philosophy, namely as indicating 1) the “source of sensibility" (感性的来源); 2) the limits of knowledge

21 Accordingly, for $\mathrm{Li}$, " $\mathrm{t}]$ he synthetic method is more important and fundamental than the analytic method, because the former reflects the fact that practice transforms and manages objects in actual activities and breaks through old relationships to establish new ones, hence constituting a historical process that evolves from the simple to the complex” “综合”所以比“分析”更为重要更为根本, 原因在于: 它反映了实践在现实活动中改造对象、消化对象, 打破旧关系, 建立新关系, 造成不断由简单到复杂的历史历程) (Li 2018/[1979], 61/82-83, translation amended). 
(知识的界限); and 3) a concept of reason (理性的理念), with this last aspect occupying an intermediary position in between the epistemological and ethical dimensions of Kant's whole philosophical enterprise. For Li, the most basic sense of the thing in itself, and what immediately presents itself as its most ostensibly "materialist" quality, is that of affirming the ontological independence of the external, materially constituted world as the origin of human sensibility. As such, the thing in itself is meant to serve as a conceptual guarantee for the irreducibility of the world to consciousness or thought, for the fact that it exists "objectively", insofar as its existence does not coincide with its phenomenal appearance to the subject, or, in other words, for its basic facticity. In short then, the thing in itself functions as a safeguard against an idealism of the type found in Berkeley, asserting the irreducible facticity of the world in its "thingness", as an "in itself" of which the existence is not contingent upon appearing to the human subject. As is well-known, in Kant's philosophy this basic "materialist" gesture is accomplished by stressing the dependence of knowledge on sensibility. Hence, as Li nicely puts it, " $[t]$ he 'trans' in the theory of the transcendental concepts of the understanding (categories) refers to mere logical possibility, while the actuality of knowledge depends on sensibility” (先验知性概念 (范畴) 之所谓“先”，只是就逻辑的可能 性面言, 认识的现实性是必须由感性来提供的) (Li 2018/[1979], 191/242). In other words, Kant's transcendentalism does not start out from the transcendent, but rather from the primacy of the empirical.

At the same time however, Li believes that "the most well-known feature" (最著 名的特征) ( $\mathrm{Li}$ [1979], 243) of the thing in itself, namely the fact that it cannot be known and remains categorically foreclosed to human knowledge as conditioned and constrained by sensibility, ends up undermining its status as a gatekeeper of "materialism". He even goes so far as to claim that "[ $t]$ he conception of the unknowability of the thing in itself [...] has not only served as a weapon that idealism carries into the fight with materialism, but also counts as an internal defect of the old materialism itself” (它不但是唯心主义反对唯物主义的一种武器, 同 时还是旧唯物主义自身的一种内在缺陷) (Li 2018/[1979], 192/243-44, translation amended). This leads us straight into the second and closely related aspect of the thing in itself identified by $\mathrm{Li}$, namely its function as designating a limit to knowledge. For Li, the assumption that the thing in itself must be (and always will remain) "in itself" and can never become something "for us" ultimately proves to be the undoing of its "thingness", that is to say, its usefulness in pointing toward the materiality of the world as non-reducible to consciousness, precisely because it blinds us to how our knowledge of reality is essentially the product of human practice in society. In an earlier version of this chapter, ${ }^{22} \mathrm{Li}$ still approvingly

22 A shortened version of this chapter was already published as a separate article in Zhexue yanjiu 哲学研究 (Philosophical Researches) a year earlier (see Li 1978). In the postface to the thirtieth 
invoked Lenin's observation in the Pbilosophical Notebooks according to which "[w] hen Kant assumes that something outside us, a thing-in-itself, corresponds to our ideas, he is a materialist. When he declares this thing-in-itself to be unknowable, transcendental, other-sided, he is an idealist." (Lenin 1908, quoted in Li 1978, 44)

Li Zehou's more detailed line of reasoning hones in on the two layers of meaning of the thing in itself he discerns in Kant's Critique of Pure Reason as a limiting concept: on the one hand, it refers to the "transcendental object", that it to say, the wholly indeterminate concept of any object whatsoever (called "transcendental object = X" in the first edition of Kant's Critique) which lies at the basis of the unity of the sensible manifold in our representations of things as phenomena (hence to be distinguished from a "transcendent object" or "noumenon" in the strict sense of the term, since it is still something which, structurally and formally speaking, “actually enters into the cognitive process” (实际已进入人的认识过程). On the other hand, the thing in itself also includes a subjective aspect, insofar as it designates the pure "I think", i.e. the transcendental unity of apperception, which Kant believes must necessarily accompany all subjective representations, without however allowing the actual thinking subject (as a part of empirical reality) to have access to or knowledge of itself otherwise than as phenomenally determined (and not as it is in itself) (Li 2018/[1979], 194/247). Hence, the categorical enclosure of knowledge within the realm of the phenomenal applies as much to the objective as to the subjective dimensions of cognition, meaning that we are no more capable of peering into the inner constitution of ourselves than we are able of observing things "out there" as they are in themselves. While the subject is obviously the locus of the transcendental par excellence insofar as it is home to the a priori categories of the understanding which make knowledge possible, it is does not occupy a privileged position as a site of self-transparency at all, since any form of reflexive orientation toward the "inner sense" of the self ultimately cannot but encounter the same boundaries which condition the observation of external entities (see for example Kant 2007, 81, B69; 154, B156; 275, B334).

For $\mathrm{Li}$, all of this implies that while "both [the transcendental object and the transcendental unity of apperception] are necessary conditions of human knowledge, they themselves are beyond the reach of experience and possible knowledge" ( 都是人们进行认识的必要条件, 他们本身都超出人们经验的和认识可能) (Li 2018/[1979], 195/248, translation amended). Because of this fundamental unresolved tension between the subjective and objective aspects of the unknowable "in itself" and the failure to provide a common ground between them in the Kantian system, Li claims that " $[\mathrm{t}]$ hey always attempt to gobble each other

anniversary edition (the 6th) of his Critique, Li notes that his analysis of the thing in itself was one of the sections which was "significantly revised in both interpretation and style," without however deviating from "the anthropological ontology I laid out in the first edition" (Li 2018, 345). 
up, so that the one comes to be derived from the other” (总是一个要吞并另一 个, 由一个推演出另一个) a tendency with considerable and largely delirious consequences in the post-Kantian development of transcendental philosophy, the most commonly taken path being that of completely imploding objectivity (the independence of the material world) into an overinflated and reified form of subjectivity, that is to say a Fichtean "I", Hegelian "Spirit", or Schopenhauerian "Will" (see Li 2018/[1979], 196-98/249-53). Ironically then, in Li's opinion, the "materialist" intentions undergirding Kant's assertion of the existence of things in themselves as distinct from phenomena historically gave rise to the worst possible forms of idealism.

To what he identifies as an irresolvable antinomy between the subjective and objective aspects of the "in itself" as a limit to knowledge in Kant's Critique of Pure Reason, Li Zehou opposes an assertion of the primordial status of "practice" (shijian 实践) which follows the basic presuppositions of his own historical ontology. For Li, human subjectivity as subjectality constitutes, not simply another "object" of perception and knowledge, which would bring it face to face with the latter's inescapable limiting conditions and with the "in itself" as the gatekeeper of the primacy of sensibility, but rather a veritable "feedback system" (Li 1999, 180) capable of increasing its own "cognitive power" with the development of society throughout history. The sort of “supra-biological” (超生物的) practice of which human beings are the only possible subjects (i.e. engaging in labour and transforming both themselves and their physical as well as cultural environment through the creation and manipulation of tools) allows them “reveal" (揭示) the thing in itself in its objective aspect (i.e. as the transcendental object $=\mathrm{X}$ ). Moreover, this practice itself coincides with the subjective aspect of the noumenal, that is to say, with subjectality as the transcendental unity of the subject ( $\mathrm{Li}$ 2018/ [1979], 201/256). While Li's line of reasoning as to how this is supposed to work at a more concrete level of theoretical analysis remains opaque, it is in my view significant that he goes on at this point to quote the following famous but highly problematic passage from Engels's tract Ludwig Feuerbach and the End of Classical German Philosophy:

the most telling refutation of this as of all other philosophical crotchets is practice-namely, experiment and industry. If we are able to prove the correctness of our conception of a natural process by making it ourselves, bringing it into being out of its conditions and making it serve our own purposes into the bargain, then there is an end to the Kantian ungraspable "thing-in-itself". The chemical substances produced in the bodies of plants and animals remained just such "things-in-themselves" until organic chemistry began to produce them one after another, whereupon the "thing-in-itself" became a thing for us. (Engels 1886, no pagination) 
For a commentator as informed as $\mathrm{Li}$, it is strange to say the least that he does not seem to notice or take the trouble to indicate how Engels's reading of the thing in itself as a mere "philosophical crotchet" conveniently substitutes an empirical distinction for a transcendental one. By any account, the Kantian distinction between phenomena and things in themselves has nothing to do with the difference between, say, my subjective ignorance of the chemical makeup of the transparent, thirst-quenching liquid which I hold before me in a glass on the one hand, and the objective knowledge communicated to me by a person wearing a white labcoat that this is in fact $\mathrm{H}_{2} \mathrm{O}$, a chemical compound which reacts in such and such manner with other substances. For Kant, these two observations, while certainly not equally "objective" or scientifically valid, are nonetheless both subject to the (spatiotemporal) conditions of sensibility and the mediating influence of the $a$ priori concepts of the understanding with which human beings are equipped. The fact that we might, under certain contingent societal conditions, become able to "produce" $\mathrm{H}_{2} \mathrm{O}$ has no bearing on the latter's epistemological status at all. In other words, while we certainly know the phenomenon "water" better and more adequately in being able to recognize it as $\mathrm{H}_{2} \mathrm{O}$, this has not brought us an inch closer to its being as an "in itself", and indeed, from a Kantian perspective, such a leap to the "in itself" is not a necessary requirement for the growth of scientific knowledge. In this regard, we might recall that Kant draws a helpful distinction between "limits" (Scbranken) and "bounds" (Grenzen), in order to indicate that science has no "bounds" and can continue to grow and progress indefinitely, as long as it does not overstep the categorical "limits" of sensibility, beyond which the categories of the understanding are of no use whatsoever (see Westphal 1968, 131).

While my intention here is not to belabour the rather obvious point that $\mathrm{Li}$ is not an orthodox Kantian (by his own admission, he is not), it is still worth pointing toward this peculiar substitution of the empirical for the transcendental, precisely because $\mathrm{Li}$ himself is otherwise very careful to avoid conflating the two. The above-mentioned difference between "transparent thirst-quenching liquid" and " $\mathrm{H}_{2} \mathrm{O}$ " does not require the intricate conceptual machinery of Kantian transcendentalism, but can be described very well by using the much more simple opposition between the "subjective" and the "objective", although such a straightforward form of realism leaves much to be desired both from an epistemological and an ontological point of view, and would beg the question as to why $\mathrm{Li}$ would take the trouble to concern himself with Kant's critical philosophy in the first place. At this point in his intellectual development, $\mathrm{Li}$ is not yet ready to jettison the idea of the thing in itself and the transcendental altogether, but his "materialist" challenge to its putative unknowability threatens to severely compromise its status as an epistemological limiting-concept. As such, this indicates that Li's approach to the thing in itself involves a strong discontent with epistemological restrictions which are read as normatively undermining the autonomy of human "subjectality". 


\section{Coda: Facticity and Unknowability}

What is perhaps more problematic about the idea of the thing in itself becoming a "thing for us" in the sense envisaged by Engels is the considerable risk of completely overriding the facticity which Li Zehou himself admits the notion of the thing in itself was originally meant to vouchsafe within the architectonic of Kant's system of philosophy. After all, if "subjectality" comes to be seen as a self-determining structure which not only accounts for the formation and application of relatively stable cognitive and experiential structures, but also for the actual content of knowledge and experience, as Li seems to suggest at times (see for example Li 2018/[1979], 90/117), it arguably becomes hard to distinguish it from the sort of hyper-inflated conception of subjectivity of the kind Li faults Fichte, Hegel, and Schopenhauer for. Indeed, for figures in modern intellectual history as diverse (and at times diametrically opposed) as Lukács, Heidegger, and Adorno, the thing in itself serves before all else as a philosophical signpost of the problem of facticity, for "the impossibility of reducing contents to their rational elements" (Lukács [1923], 116), for the ontological horizon of human finitude (Heidegger [1929]), for the awareness of how the objective world operates as a "block" and the concomitant refusal to "generate everything that exists from the realm of consciousness" (Adorno 2001, 18). ${ }^{23}$ In this regard, Li's efforts to reinterpret the thing in itself in a positive light as signalling toward the materiality or "thingness" of the world and its ontological independence from human subjectivity finds itself in an uneasy relation with his much more concerted and sustained attempt to undercut its status as an unknowable "in itself". Indeed, Li's discussion of the third aspect Kant's concept, namely its status as a regulative "idea of reason" which redirects human beings from epistemology to ethics, or from reason to belief, that is to say, to properly normative considerations, is mostly intended to reiterate his conviction that a resolution to the unknowability of the thing in itself can be provided by social practice as the site of conciliation between subjectivity and objectivity (see Li 2018/ [1979], 207-209/364-67). Perhaps it is not by accident then that in Li's more recent work, the thing in itself makes a new appearance as a designation for the unknowable, even if the later is still described in strictly materialist terms. The looming erasure of all facticity within the concept of subjectality would seem to

23 "Kant $[\ldots]$ would rather acquiesce in the inconsistencies to which we have repeatedly drawn attention than create a seamless intellectual harmony which nevertheless would prevent him from delivering on his specific philosophical ambitions. To take matters to their logical conclusions means denying the existence of the block and laying claim to absolute identity. The dialectical or antinomic structure of Kantian philosophy means that it aspires to create a system, to provide a central point, which is that of the idea that can construct reality-but at the same time, it refuses to regard the world as identical with that idea [...] I believe this is the deepest thing to be found in Kant.” (Adorno 2001, 177) 
have led $\mathrm{Li}$ to reembrace the unknowability of the thing in itself in a different fashion, precisely in order to reassert the limitations of human knowledge, and thus, in a sense, of our own existence as well:

The reason why the universe exists and the fact that it exists in this specific way at all (that is to say, why its existence is orderly to begin with, or qualifies as what I call a "syncretistic form of communal being") cannot be known or explained rationally. (The specific laws governing the universe and nature accessible through experience on the other hand are inventions or "discoveries" of human beings, and can be known and explained.) I believe that Kant's transition from the "antinomies of reason" to the profundity of the noumenal as something unknowable has to be understood from this perspective as well. What we are dealing with here is the "mystery of reason".

宇宙存在和在根本上会如此这般的存在（即这存在为何在根本上 具有规律性，即 “协同共在”）是不可以用理知去认识、解说的（ 至于可经验的宇宙一自然存在的具体规律性，则是人的发明或“发 现”，即可认识解说的）。Kant由“二律背反”走向不可知的“物自体” 的深刻性, 我以为也在这里。这是“理性的神秘”。) ( Li 2016, 569; cf. Li 2008, 53-54, 111-13; Li 2018, vii

\section{References}

Adorno, Theodor. 2001. Kant's Critique of Pure Reason. Stanford: Stanford University Press.

Burtscher, Michael. 2006. "Facing 'the West' on Philosophical Grounds: A View from the Pavilion of Subjectivity on Meiji Japan." Comparative Studies of South Asia, Africa, and the Middle East 26 (3): 367-76.

Cheng, Gongrang 程恭让. 2001. "Yi foxue qijie Kangde: Liang Qichao de Kangdexue geyi 以佛学契接康德: 梁启超的康德学格义 (Connecting Kant with Buddhism: Liang Qichao's "Analogical Interpretation” of Kantianism).” Zhexue yanjiu 哲学研究 (Philosophical Researches) 2: 37-44.

Chong, Woei Lien. 1999. "Combing Marx with Kant: the Philosophical Anthropology of Li Zehou." Philosophy East and West 49 (2): 120-49.

Engels, Friedrich. 1886. "Ludwig Feuerbach and the End of Classical German Philosophy.” Accessed February 22, 2019. https://www.marxists.org/archive/ marx/works/1886/ludwig-feuerbach/ch02.htm.

Heidegger, Martin. [1927] 1967. Being and Time. Translated by John Macquarrie and Edward Robinson. Oxford: Basil Blackwell. 
- [1929] 1997. Kant and the Problem of Metaphysics. Bloomington and Indianapolis: Indiana University Press.

Huang, Kewu. 2004. "Liang Qichao and Immanuel Kant." In The Role of Japan in Liang Qichao's Introduction of Modern Western Civilization to China, edited by Joshua A. Fogel, 125-55. Berkeley: Institute of East Asian Studies.

Kang, Youwei 康有为. [1930] 2007. “Zhutian jiang 諸天講 (On the Heavens)." In Kang Youwei quanji 康有为全集 (The Complete Works of Kang Youwei), edited by Jiang Yihua 姜义华 and Zhang Ronghua 张荣华, vol. 12, 1-132. Beijing: Zhongguo renmin daxue chubanshe.

Kant, Immanuel. 2007. Critique of Pure Reason. Translated by Marcus Weigelt. London: Penguin Books.

Kurtz, Joachim. 2011. "Domesticating a Philosophical Fiction: Chinese Translations of Kant's 'Things-in-Themselves." Concept and Communication 6: 165-200.

Lee, Ming-huei (Li Minghui) 李明辉. 2016. “Kangde zhexue zai xiandai Zhongguo 康德哲学在现代中国 (Kant's Philosophy in Modern China).”In Kangde zhexue zai dongya 康德哲学在东亚 (Kant's Philosophy in East Asia), edited by Li Minghui, 1-42. Taibei: Guoli Taiwan daxue chuban zhongxin.

—. 2018. "Kangde "wu zishen" gainian heyi you jiazhi yihan. Lun Mou Zongsan de quanshi jin yi jie 康德的“物自身”概念何以有价值意涵——为牟宗 三的诠释进一解 (Why Does Kant's Concept of the Thing in Itself Have an Axiological Significance? A Further Interpretation of Mou Zongsan's Reading).” Guoxue yuekan 国学月刊 (Montbly Journal of National Studies) 1: 64-73.

Lenin, Vladimir. 1908. Materialism and Empirico-Criticism. Accessed February 25, 2019. https://www.marxists.org/archive/lenin/works/1908/mec/.

Li, Zehou 李泽厚. 1956. “Lun meigan, mei, yu yishu 论美感、美与艺术 (On Aesthetic Feeling, Beauty, and Art).” Zhexue yanjiu 哲学研究 (Philosophical Researches) 5: 43-73.

—. 1978. “Guanyu Kangde de “wu ziti” xueshuo 关于康德的“物自体”学说 (On Kant's Doctrine of the 'Thing in Itself').” Zhexue yanjiu 哲学研究 (Philosophical Researches) 6: 43-52.

- - [1979] 2007. Pipan zhexue de pipan: Kangdepingshu 批判哲学的批判: 康德 述评 (A Critique of Critical Philosophy: An Appraisal of Kant). Beijing: Sanlian shudian. English translation by Jeanne Haizhen Allen and Christopher Ahn, A Nerw Approach to Kant, Singapore: Springer, 2018.

- 1985. Zhongguo gudai sixiang shi lun 中国古代思想史论 (On the History of Ancient Chinese Thought). Beijing: Renmin chubanshe.

—. 1999. "Subjectivity and Subjectality: A Response." Philosophy East and West 49 (2): 174-83.

-2000. "A Supplementary Explanation of Subjectivity." Contemporary Chinese Thought 31 (2): 26-31. 
—. 2008. Shiyong lixing yu legan wenhua 实用理性与乐感文化 (Pragmatic Reason and the Culture of Optimism). Beijing: Sanlian shudian.

—. 2010. The Chinese Aesthetic Tradition. Translated by Maija Bell Samei. Honolulu: University of Hawai'i Press.

—. 2016. Renleixue lishi bentilun 人类学历史本体论 (An Anthropological-Historical Ontology). Qingdao: Qingdao chubanshe. (Note: this is a revised and expanded edition of Zhexue gangyao 哲学纲要 (Outlines of Philosophy) from 2011 published by Beijing daxue chubanshe).

- 2018. The Origins of Chinese Thought: from Shamanism to Ritual Regulations and Humaneness. Translated by Robert A. Carleo III. Leiden and Boston: Brill.

Li, Zehou 李泽厚, and Jane Cauvel. 2006. Four Essays on Aesthetics: Toward a Global View. Lanham: Lexington Books.

Liu, Kang. 1992. "Subjectivity, Marxism, and Culture Theory in China." Social Text 31 (32): 114-40.

Luhmann, Niklas. 2013. Introduction to Systems Theory. Cambridge: Polity Press. Lukács, György. [1923] 1971. History and Class Consciousness. London: Merlin Press.

Mou, Zongsan 牟宗三. [1975] 2003. Xianxiang yu wuzishen 現象與物自身 (Appearance and Thing in Itself). In The Complete Works of Mou Zongsan (Mou Zongsan xiansheng quanji 牟宗三先生全集), vol. 21. Taibei: Liangjing.

Müller, Martin. 2006. "Aspects of the Chinese Reception of Kant." Journal of Chinese Philosophy 33 (1): 141-56.

Rescher, Nicholas. 1981. "On the Status of 'Things in Themselves' in Kant." Synthese 47 (2): 289-99.

Rockmore, Tom. 2010. "Fichte, German Idealism, and the Thing in Itself." In Fichte, German Idealism, and Early Romanticism, edited by Daniel Breazeale and Tom Rockmore, 9-20. Amsterdam and New York: Rodopi.

Rošker, Jana. 2019. Following his Own Path: Li Zehou and Contemporary Chinese Philosophy. Albany: State University of New York Press.

Schrader, George A. 1949. "The Thing in Itself in Kantian Philosophy." The Review of Metaphysics 2 (7): 30-44.

Vallicella, William F. 1983. "Kant, Heidegger, and the Problem of the Thing in Itself." International Philosophical Quarterly 23 (1): 35-43.

Van den Stock, Ady. 2016. The Horizon of Modernity: Subjectivity and Social Structure in New Confucian Philosophy. Leiden and Boston: Brill. - (Forthcoming). "There and Back Again: On Li Zehou's (Anti-) Philosophy and the Lure of the Beyond." In Beyond Comparisons: Three Exemplars of Ru 儒, edited by Geir Sigurðsson and Paul J. D’Ambrosio.

Wang, Jing. 1996. "Li Zehou and the Marxist Reconstruction of Confucianism." In High Culture Fever: Politics, Aesthetics, and Ideology in Deng's China, 93-117. Berkeley: University of California Press. 
Wen, Bing 文炳, and Chen Jiaying 陈嘉映. 2011. “Xiantian', 'xianyan', 'chaoyan’ yiming yuanliu kao “先天”、“先验”、“超验”译名源流 (An Investigation into the Origins of the Translated Terms xiantian 先天, xianyan 先验, and chaoyan 超验).” Yunnan daxue xuebao 云南大学学报 (Journal of Yunnan University) 10 (3): 3-10.

Westphal, Merold. 1968. "In Defense of the Thing in Itself." Kant-Studien 59: 118-41.

Xu, Bo. 2016. “The Reception of Kant in China." In Liberalism and Chinese Economic Development: Perspectives from Europe and Asia, edited by Gilles Campagnolo, 25-48. London and New York: Routledge.

Zhao, Tingyang. 2009. "A Political World Philosophy in Terms of All-under-Heaven (Tian-xia)." Diogenes 56 (1): 5-18. 